ISSN : $2338-4794$

Vol. 5. No. 1 Januari 2017

\title{
STRATEGI PERENCANAAN AGREGAT SEBAGAI PILIHAN KAPASITAS PRODUKSI
}

\author{
Harry Indra *) \\ Program Studi Manajemen UNKRIS \\ Alamat: Kampus UNKRIS, Jatiwaringin Jakarta Timur \\ Email: harryindrahandrito@yahoo.co.id
}

\begin{abstract}
The purpose of this research is to provide solutions that can be given to firm to face the problems and to provide recommendations that can be given to the company to fulfill the order request number in a timely manner and achieve a level of production that the company expected. In this research, these problems can be resolved with 2 steps. First, forecasting consumer demand in the future with 4 methods, Linear Regression, Moving Average, Weighted Moving Average and Exponential Smoothing based on previous demand data and Second, using aggregate planning methods with 3 alternative strategies, there are Chase Strategy, Level Strategy and Mixed Strategy. Advice can be given to company is where firm can implement Mixed strategy, because this strategy has the most minimal total cost of production compared to 2 others strategies
\end{abstract}

Kata kunci: Strategi perencanaan agregat dan kapasitas produksi

\section{PENDAHULUAN}

Seiring berjalannya waktu, akan banyak masalah yang ditemui dalam persaingan, apalagi dengan diberlakukannya Masyarakat Ekonomi ASEAN (MEA) pada akhir tahun 2015yang lalui. Akan banyak bermunculan perusahaan-perusahaan asing dengan kualitas produk dan harga yang bersaing. Salah satu cara untuk menghadapi masalah persaingan yang akan sering muncul adalah meningkatkan kualitas dari suatu produk, memperhatikan apa yang menjadi keinginan dan kebutuhan para konsumen. Jika suatu perusahaan dapat terus berusaha meningkatkan kinerjanya, maka selama itulah perusahaan dapat bertahan dalam pesatnya kompetisi global.

Peramalan atau perencanaan jumlah permintaan sangatlah penting diketahui oleh setiap perusahaan atau para pelaku bisnis, karena peramalan permintaan berkaitan dengan persediaan produk yang dimiliki oleh perusahaan. Perusahaan atau pelaku bisnis sebaiknya melakukan perencanaan dengan menggunakan metode yang sudah ada ataupun menggunakan sistem, karena jika tidak adanya peramalan terhadap jumlah stok memungkinkan akan terjadinya hal yang tidak diinginkan oleh perusahaan. Misalnya, jumlah stok barang tidak dapat memenuhi permintaan konsumen atau bisa juga kelebihan dalam proses produksi.

\section{METODE PENELITIAN}

\section{Kriteria Optimasi:}

Variabel yang digunakan dalam penelitian ini adalah perencanaan agregat. Beberapa hal yang dibutuhkan untuk menghitung perencanaan agregat adalah: a). Kapasitas jam kerja perusahaan; Kapasitas jam kerja yang diterapkan oleh perusahaan yaitu 8 jam dalam satu hari (istirahat 1 jam) dan untuk kapasitas jam kerja pada saat lembur yang dapat diberikan oleh perusahaan yaitu 10 hari dalam sebulan dan hanya 2 jam. b). Kapasitas Produksi; Kapasitas produksi merupakan kapasitas yang dimiliki oleh 
perusahaan untuk melakukan proses produksi. Kapasitas produksi dipengaruhi oleh kecepatan produksi dan ketersediaan jam kerja yang ada selama periode perencanaan. Berdasarkan wawancara dengan bagian produksi, kapasitas maksimum perusahaan dalam memproduksi produk sebanyak 1.600 ton per bulan. c). Kecepatan Produksi; Berdasarkan wawancara dengan bagian produksi, kecepatan produksi rata-rata dari proses produksi adalah 0,13 jam per ton. d). Biaya Produksi; Data pendukung yang berperan penting dalam perhitungan perencanaan agregat adalah informasi biaya produksi. Informasi biaya produksi ini adalah biaya penanganan persediaan, tingkat upah jam kerja reguler per ton, tingkat upah jam kerja lembur dan harga bahan baku.

\section{Pengembangan Alternatif Solusi}

Metode yang diusulkan kepada perusahaan adalah dengan menggunakan metode Linear Regression, Moving Average, Exponential Smoothing dan Weighted Moving Average untuk mengetahui hasil peramalan periode berikutnya serta menggunakan strategi Chase Strategy, Level Strategy dan Mixed Strategy untuk mengetahui strategi perencanaan agregat terbaik yang dianalisis menggunakan software POM$Q M$ for Windows berdasarkan peramalan permintaan periode 2015-2016, kapasitas produksi, kapasitas jam kerja dan biaya produksi.

Jenis penelitian yang dilakukan dalam penelitian ini adalah Deskriptif, suatu penelitian yang dlakukan dengan mengetahui nilai variabel mandiri, baik satu variable atau lebih (independen) tanpa membuat perbandingan, atau menghubungkan dengan variabel lain, sedangkan metode penelitian yang dilakukan adalah melalui Observasi dengan unit analis dan time horizon digunakan, yaitu cross sectional (penelitian yang dilakukan dalam kurun waktu tertentu).

Tabel 1: Jenis Dan Sumber Data

\begin{tabular}{|c|c|c|c|}
\hline Tujuan & Data & $\begin{array}{c}\text { Sumber } \\
\text { Data }\end{array}$ & $\begin{array}{l}\text { Jenis } \\
\text { Data }\end{array}$ \\
\hline $\mathrm{T}-1$ & $\begin{array}{l}\text { Menentukan } \\
\text { alternatif metode } \\
\text { peramalan yang } \\
\text { paling tepat } \\
\text { diterapkan pada } \\
\text { perusahaan } \\
\text { untuk } \\
\text { meramalkan } \\
\text { permintaan } \\
\text { berikutnya. }\end{array}$ & $\begin{array}{l}\text { Sekunder - } \\
\text { Perusahaan }\end{array}$ & Ratio \\
\hline $\mathrm{T}-2$ & $\begin{array}{l}\text { Menentukan } \\
\text { strategi } \\
\text { perencanaan } \\
\text { agregat yang } \\
\text { paling tepat } \\
\text { dilakukan oleh } \\
\text { perusahaan } \\
\text { untuk } \\
\text { meminimalisasi } \\
\text { biaya produksi }\end{array}$ & $\begin{array}{l}\text { Sekunder - } \\
\text { Perusahaan }\end{array}$ & Ratio \\
\hline
\end{tabular}

\section{Desain Penelitian}

Desain Penelitian merupakan perencanaan, struktur dan strategi penelitian dalam rangka menjawab pertanyaan dan mengendalikan penyimpangan yang mungkin terjadi. (Murti Sumarmi,Salamah Wahyuni,2005)

Tabel 2: Desain Penelitian

\begin{tabular}{|c|c|c|c|}
\hline \multirow{2}{*}{$\begin{array}{c}\text { Tujuan } \\
\text { Penelitian }\end{array}$} & \multicolumn{3}{|c|}{ Desain Penelitian } \\
\cline { 2 - 4 } & $\begin{array}{c}\text { Jenis dan } \\
\text { Metode }\end{array}$ & $\begin{array}{c}\text { Unit } \\
\text { Analysis }\end{array}$ & $\begin{array}{c}\text { Time } \\
\text { Horizon }\end{array}$ \\
\hline T-1 & Deskriptif & $\begin{array}{l}\text { Observasi } \\
\text { bagian } \\
\text { produksi }\end{array}$ & $\begin{array}{l}\text { Cross } \\
\text { Sectional }\end{array}$ \\
\hline T-2 & Deskriptif & $\begin{array}{l}\text { Observasi } \\
\text { bagian } \\
\text { produksi }\end{array}$ & $\begin{array}{l}\text { Cross } \\
\text { Sectional }\end{array}$ \\
\hline
\end{tabular}

Sumber: Data Olahan Penelitian, 2016

\section{Keterangan:}

T-1 : Menentukan alternatif metode yang paling tepat diterapkan pada 
perusahaan untuk meramalkan permintaan berikutnya.

T-2 : Menentukan strategi perencanaan agregat yang paling tepat dilakukan oleh perusahaan untuk meminimalisasi biaya produksi

Perencanaan Agregat (Aggregate Planning) dianalisis menggunakan Software POM-QM for Windows dengan menerapkan tida strategi perencanaan agregat, yaitu Chase Strategy, Level Strategy dan Mixed Strategy.

Perumusan strategi perencanaan agregat adalah sebagai berikut: 1). Chase Strategy merupakan strategi perencanaan yang menetapkan produksi sama dengan prediksi permintaan (produksinya disesuaikan dengan permintaan). Strategi ini mencoba untuk mencapai tingkat output untuk setiap periode yang memenuhi prediksi permintaan untuk periode tersebut. Sebagai contoh, manajer operasi dapat mengubah-ubah tingkat tenaga kerja dengan merekrut atau memberhentikan karyawan, atau dapat mengubah-ubah jumlah produksi dengan waktu lembur, waktu kosong, karyawan paruh waktu, atau subkontrak.Banyak organisasi jasa menyukai strategi perburuan ini karena pilihan persediaan sangatlah sulit atau mustahil untuk diadopsi.Industri yang telah beralih ke strategi perburuan meliputi sektor pendidikan, perhotelan, dan konstruksi. Kelebihan chase strategy adalah : a). Investasi pada persediaan rendah dan b). Tingkat penggunaan tenaga kerja yang tinggi (high labor utilization). dan kekurangan dari chase strategy adalah sebagai berikut: Kekurangan chase strategy: Terdapat biaya untuk memperbaiki tingkat keluaran dan/atau tingkat angkatan kerja. 2). Level Schedulling Strategy; Strategi penjadwalan tingkat (level scheduling strategy) adalah rencana agregat di mana tingkat produksi tetap sama dari periode ke periode (produksinya konstan).
Penjadwalan tingkat mempertahankan tingkat output, tingkat produksi, atau tingkat tenaga kerja yang konstan pada horizon perencanaan. Perusahaan seperti Toyota dan Nissan mempertahankan tingkat produksi mereka pada tingkat yang seragam dan memungkinkan untuk membiarkan persediaan produk mereka naik atau turun untuk menopang perbedaan antara jumlah permintaan dan produksi atau menemukan pekerjaan alternatif bagi karyawan.Filosofi mereka adalah tenaga kerja yang stabil menciptakan produk dengan kualitas lebih baik, lebih sedikit perputaran karyawan dan ketidakhadiran, serta karyawan yang lebih berkomitmen terhadap tujuan perusahaan.

Penghematan lain mencakup karyawan yang lebih berpengalaman, penjadwalan dan pengawasan yang lebih mudah, serta lebih sedikit pembukaan dan penutupan usaha yang dramatis. Penjadwalan bertingkat akan bekerja dengan baik ketika permintaan cukup stabil. Kelebihan level scheduling strategy adalah Tingkat keluaran dan angkatan kerja yang stabil. dan kekurangan level scheduling strategy: adalah sebagai berikut: a). Biaya persediaan yang tinggi. b). Meningkatkan overtime dan idle time. c). Utilisasi sumber daya bervariasi dari waktu ke waktu. 3). Mixed Strategy; Strategi ini melibatkan pengubahan lebih dari satu variabel yang dapat di kontrol (controllable decision variable). Beberapa kombinasi dari pengubahan variabel yang dapat dikontrol dapat menghasilkan suatu strategi perencanaan agregat yang terbaik. Menurut Simamora dan Natalia (2014), mixed strategy merupakan pencampuran antara chase dan level strategy, dengan memperhitungkan kelebihan dan kekurangan chase dan level strategy dengan tujuan untuk mengurangi dampak negatif dari alternatif pure strategy. 


\section{HASIL DAN PEMBAHASAN}

Berikut ini adalah hasil perhitungan Metode Peramalan dengan menggunakan QM for Windows :

Tabel 3: Simpulan Peramalan

\begin{tabular}{|c|c|c|}
\hline Metode & MAD & MSE \\
\hline $\begin{array}{c}\text { Linear } \\
\text { Regression }\end{array}$ & 535,504 & $390.418,1$ \\
\hline $\begin{array}{c}\text { Moving } \\
\text { Average }\end{array}$ & 364,1851 & $317.308,4$ \\
\hline $\begin{array}{c}\text { Exponential } \\
\text { Smooting }\end{array}$ & 394.2026 & $375.151,2$ \\
\hline $\begin{array}{c}\text { Weighted } \\
\text { Moving } \\
\text { Average }\end{array}$ & 324,381 & $290.588,8$ \\
\hline
\end{tabular}

Sumber: Hasil Pengeolahan Data, 2015

Dari tabel diatas, terlihat bahwa peramalan dengan menggunakan pendekatan Weighted Moving Average memiliki hasil MAD dan MSE terendah, yaitu sebesar 324,381 dan 290.588,8 yang dapat diartikan bahwa peramalan dengan menggunakan pendekatan Weighted Moving Average memiliki tingkat kesalahan peramalan paling terkecil.

Pada penelitian ini penulis menggunakan alternatif overtime untuk strategi yang dilakukan, dikarenakan perusahaan tidak menggunakan alternatif subkontrak atau strategi lainnya. Alternative overtime dilakukan untuk menjaga mutu dan kualitas produk yang di produksi oleh perusahaan, sehingga perusahaan lebih memilih untuk melemburkan karyawannya untuk memenuhi permintaan yang berlebih dan membayar gaji karyawan yang dilemburkan lebih besar dari gaji karyawan pada waktu regular.

Berikut alternatif overtime yang digunakan penulis:

1). Chase Strategy; Chase strategy adalah strategi untuk menghasilkan jumlah produk yang sesuai dengan perkiraan permintaan untuk bulan itu. Strategi ini tidak memiliki biaya penanganan persediaan (inventory cost). Perusahaan harus memproduksi sesuai dengan jumlah produk yang tepat sesuai permintaan melalui produksi reguler, produksi lembur maupun subkontrak.

\begin{tabular}{|c|c|c|c|c|c|c|}
\hline \multirow{2}{*}{$\begin{array}{l}\text { Shortages } \\
\text { C Backordered } \\
C \text { Lost sales }\end{array}$} & & & & \multicolumn{3}{|l|}{-Method- } \\
\hline & & & & \multicolumn{3}{|c|}{ Chase CURRENT demand (let workforce vary) } \\
\hline & & & & & \multicolumn{2}{|c|}{ (untitled) } \\
\hline Period & Demand & $\begin{array}{r}\text { Regular time } \\
\text { Capacity }\end{array}$ & $\begin{array}{l}\text { Overtime } \\
\text { Capacity }\end{array}$ & $\begin{array}{r}\text { Subcontract } \\
\text { Capacity }\end{array}$ & Unit costs & Value \\
\hline November & 1928.355 & 1333.25 & 1066.6 & 0 & Regular time & 31107730 \\
\hline December & 1630.162 & 1386.58 & 1066.6 & 0 & Overtime & 30568050 \\
\hline January & 1779.259 & 1333.25 & 1066.6 & 0 & Subcontracting & 0 \\
\hline February & 1704.71 & 1279.92 & 1066.6 & 0 & Holding cost & 0 \\
\hline March & 1741.984 & 1386.58 & 1066.6 & 0 & Backorder cost & 0 \\
\hline April & 1723.347 & 1333.25 & 1066.6 & 0 & Increase cost & 0 \\
\hline May & 1732.666 & 1279.92 & 1066.6 & 0 & Decrease cost & 0 \\
\hline June & 1728.007 & 1386.58 & 1066.6 & 0 & Initial Inventory & 0 \\
\hline July & 1730.336 & 1279.92 & 1066.6 & 0 & Units last period & 31107730 \\
\hline August & 1729.172 & 1386.58 & 1066.6 & 0 & & \\
\hline September & 1729.754 & 1333.25 & 1066.6 & 0 & & \\
\hline October & 1729.463 & 1333.25 & 1066.6 & 0 & & \\
\hline
\end{tabular}

Gambar 1: Biaya pada Chase Strategy

Sumber: Hasil Pengolahan Data, 2015 


\section{Penjelasan:}

a. Demand diperoleh dari peramalan menggunakan Weighted Moving Average, yaitu peramalan yang memiliki hasil MAD dan MSE dengan nilai yang paling rendah diantara peramalan lainnya.

b. Reguler time capacity, diperoleh dari kapasitas produksi selama jam kerja regular dalam 1 hari, yaitu 7 jam kerja setiap harinya.

c. Overtime capacity, diperoleh dari kapasitas produksi selama jam kerja lembur dalam 1 hari, yaitu 2 jam kerja setiap harinya dengan batas maksimal 10 hari lembur dalam sebulan.

Dari biaya yang digunakan dalam perencanaan agregat menggunakan Chase Strategy untuk Overtime, hasilnya yang ditemukan dengan menggunakan software POM-QM for Windows 4 adalah sebagai berikut:

\begin{tabular}{|c|c|c|c|c|c|c|c|}
\hline \multirow{2}{*}{$\begin{array}{l}\text { Shortages } \\
\text { C. Backordered } \\
C \text { Lost sales }\end{array}$} & & & \multicolumn{5}{|c|}{ Method } \\
\hline & & & \multicolumn{4}{|c|}{ Chase CURRENT demand (let workforce vary) } & 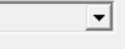 \\
\hline & & & \multicolumn{5}{|c|}{ (untitled) Solution } \\
\hline & Demand & $\begin{array}{r}\text { Regular time } \\
\text { Capacity }\end{array}$ & $\begin{array}{l}\text { Overtime } \\
\text { Capacity }\end{array}$ & $\begin{array}{r}\text { Regular time } \\
\text { production }\end{array}$ & $\begin{array}{r}\begin{array}{r}\text { Overtime } \\
\text { production }\end{array} \\
\end{array}$ & Units increase & Units decrease \\
\hline \multicolumn{8}{|l|}{ Initial Inventory = 0} \\
\hline November & 1928.355 & 1333.25 & 1066.6 & 1333.25 & 595.105 & 0 & 31106390 \\
\hline December & 1630.162 & 1386.58 & 1066.6 & 1386.58 & 243.582 & 53.33 & 0 \\
\hline January & 1779.259 & 1333.25 & 1066.6 & 1333.25 & 446.009 & 0 & 53.33 \\
\hline February & 1704.71 & 1279.92 & 1066.6 & 1279.92 & 424.79 & 0 & 53.33 \\
\hline March & 1741.984 & 1386.58 & 1066.6 & 1386.58 & 355.404 & 106.66 & 0 \\
\hline April & 1723.347 & 1333.25 & 1066.6 & 1333.25 & 390.097 & 0 & 53.33 \\
\hline May & 1732.666 & 1279.92 & 1066.6 & 1279.92 & 452.746 & 0 & 53.33 \\
\hline June & 1728.007 & 1386.58 & 1066.6 & 1386.58 & 341.427 & 106.66 & 0 \\
\hline July & 1730.336 & 1279.92 & 1066.6 & 1279.92 & 450.416 & 0 & 106.66 \\
\hline August & \begin{tabular}{|l|l|}
1729.172 \\
\end{tabular} & 1386.58 & 1066.6 & 1386.58 & 342.592 & 106.66 & 0 \\
\hline September & 1729.754 & 1333.25 & 1066.6 & 1333.25 & 396.504 & 0 & 53.33 \\
\hline October & 1729.463 & 1333.25 & 1066.6 & 1333.25 & 396.213 & 0 & 0 \\
\hline \multirow[t]{2}{*}{ Total(units) } & 20887.21 & 16052.33 & 12799.2 & 16052.33 & 4834.885 & 373.31 & 31106770 \\
\hline & & & & @\$31107730 & @ \$30568050 & @\$0 /unit & @\$0 /unit \\
\hline Subtotal Costs & & & & 3499351500000 & 3147793000000 & so & so \\
\hline Total Cost & 3647144500000 & & & & & & \\
\hline
\end{tabular}

Gambar 2: Hasil Perhitungan Chase Strategy

Sumber: Hasil Pengolahan Data, 2015

Dari gambar diatas dapat diketahui biaya-biaya yang diperoleh menggunakan Chase Strategy untuk Overtime, yaitu Total Cost yang harus dikeluarkan perusahaan adalah sebesar $\mathrm{Rp}$ 647.144.500.000,00.

2). Level Strategy; Selanjutnya, penulis menggunakan Level strategy untuk Overtime, Level Strategy merupakan strategi produksi yang menyamakan tingkat produksi pada setiap bulannya dalam suatu periode perencanaan. Strategi ini memiliki biaya penanganan persediaan dalam kegiatan produksinya. 


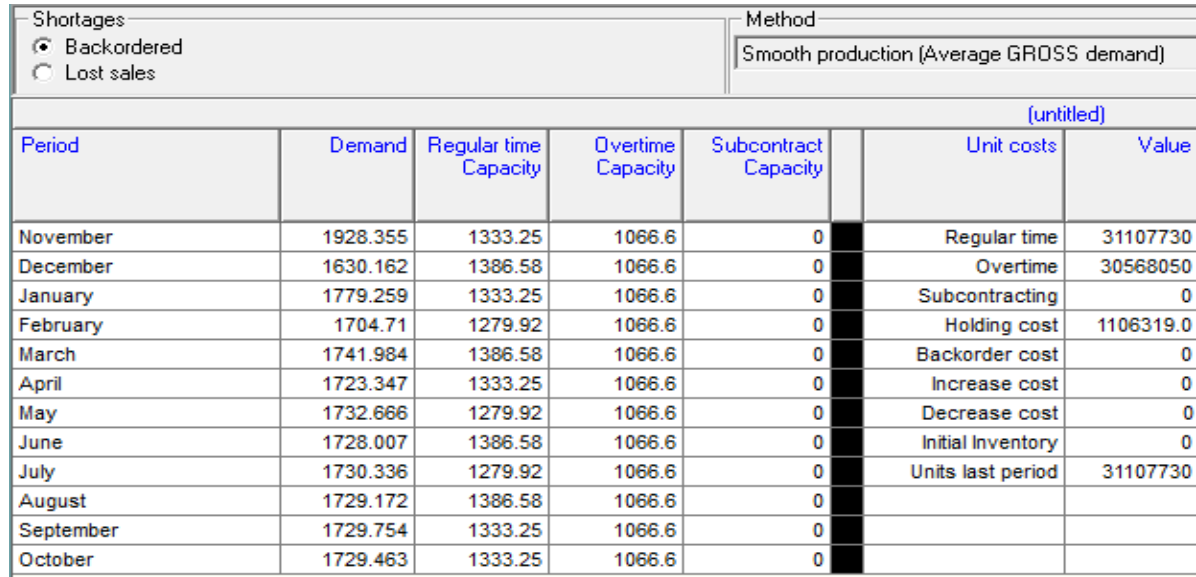

Gambar 3: Biaya pada Level Strategy

Sumber: Hasil Pengolahan Data, 2016

\section{Penjelasan:}

a. Demand diperoleh dari peramalan menggunakan Weighted Moving Average, yaitu peramalan yang memiliki hasil MAD dan MSE dengan nilai yang paling rendah diantara peramalan lainnya.

b. Reguler time capacity, diperoleh dari kapasitas produksi selama jam kerja regular dalam 1 hari, yaitu 7 jam kerja setiap harinya.

c. Overtime capacity, diperoleh dari kapasitas produksi selama jam kerja

\begin{tabular}{|c|c|c|c|c|c|c|c|c|}
\hline \multirow{2}{*}{$\begin{array}{l}\text { Shortages } \\
\text { C Backordered } \\
\subset \text { Lost sales }\end{array}$} & & & \multicolumn{5}{|c|}{ - Method } & \multirow{2}{*}{$\begin{array}{l}\text {-Instruction- } \\
\text { There are more } \\
\text { opened by usir }\end{array}$} \\
\hline & & & \multicolumn{4}{|c|}{ Smooth production (Average GROSS demand) } & $\nabla$ & \\
\hline & & \multicolumn{7}{|c|}{ (untitled) Solution } \\
\hline & Demand & \begin{tabular}{r|} 
Regular time \\
Capacity
\end{tabular} & $\begin{array}{l}\text { Overtime } \\
\text { Capacity }\end{array}$ & $\begin{array}{r}\text { Regular time } \\
\text { production }\end{array}$ & $\begin{array}{r}\text { Overtime } \\
\text { production }\end{array}$ & $\begin{array}{r}\text { Shortage (end } \\
\mathrm{PD})\end{array}$ & Units increase & Units decrease \\
\hline \multicolumn{9}{|l|}{ Initial Inventory } \\
\hline November & 1928.355 & 1333.25 & 1066.6 & 1333.25 & \begin{tabular}{|l|l}
407.75 \\
\end{tabular} & 187.355 & 0 & 31106390 \\
\hline December & 1630.162 & 1386.58 & 1066.6 & 1386.58 & 354.42 & 76.517 & \begin{tabular}{l|l}
53.33 \\
\end{tabular} & 0 \\
\hline January & 1779.259 & 1333.25 & 1066.6 & 1333.25 & \begin{tabular}{ll|l}
407.75 \\
\end{tabular} & 114.776 & 0 & 53.33 \\
\hline February & 1704.71 & 1279.92 & 1066.6 & 1279.92 & \begin{tabular}{ll|l}
461.08 \\
\end{tabular} & 78.486 & 0 & 53.33 \\
\hline March & 1741.984 & 1386.58 & 1066.6 & 1386.58 & \begin{tabular}{ll|l}
354.42 \\
\end{tabular} & 79.47 & \begin{tabular}{|l|l}
106.66 \\
\end{tabular} & 0 \\
\hline April & 1723.347 & 1333.25 & 1066.6 & 1333.25 & \begin{tabular}{|l|l|}
407.75 \\
\end{tabular} & 61.817 & 0 & 53.33 \\
\hline May & 1732.666 & 1279.92 & 1066.6 & 1279.92 & \begin{tabular}{|l|l}
461.08 \\
\end{tabular} & 53.483 & 0 & 53.33 \\
\hline June & 1728.007 & 1386.58 & 1066.6 & 1386.58 & 353.42 & 41.49 & 106.66 & 0 \\
\hline July & 1730.336 & 1279.92 & 1066.6 & 1279.92 & \begin{tabular}{|l|l|}
460.08 \\
\end{tabular} & 31.826 & 0 & 106.66 \\
\hline August & 1729.172 & 1386.58 & 1066.6 & 1386.58 & 353.42 & 20.998 & 106.66 & 0 \\
\hline September & 1729.754 & 1333.25 & 1066.6 & 1333.25 & 406.75 & 10.752 & 0 & 53.33 \\
\hline October & 1729.463 & 1333.25 & 1066.6 & 1333.25 & $\begin{array}{l}406.75 \\
\end{array}$ & .215 & 0 & 0 \\
\hline \multirow[t]{2}{*}{ Total(units) } & 20887.21 & 16052.33 & 12799.2 & 16052.33 & \begin{tabular}{|l|l|}
4834.67 \\
\end{tabular} & 757.185 & 373.31 & 31106770 \\
\hline & & & & $@ \$ 31107730$ & $@ \$ 30568050$ & @\$0/unit & @\$0 /unit & @50 /unit \\
\hline Subtotal Costs & & & & 3499351500000 & 3147786400000 & so & so & \$o \\
\hline Total Cost & 3647138000000 & & & & & & & \\
\hline
\end{tabular}

Gambar 4: Hasil Perhitungan Level Strategy

Sumber: Hasil Pengolahan Data, 2016 lembur dalam 1 hari, yaitu 2 jam kerja setiap harinya dengan batas maksimal 10 hari lembur dalam sebulan.

Dari biaya yang digunakan dalam perencanaan agregat menggunakan Level Strategy untuk Overtime, hasilnya yang ditemukan dengan menggunakan software POM-QM for Windows 4 adalah sebagai berikut: 
3). Mixed Strategy; Mixed strategy adalah gabungan dari chase dan level strategy, dengan memperhitungkan keuntungan dan kerugian dari dua strategi tersebut. Tujuannya adalah untuk menghasilkan output sesuai dengan kapasitas produksi waktu regular, waktu lembur dan subkontrak dengan optimal sehingga dapat memenuhi permintaan setiap bulannya. Strategi ini berupaya agar terhindar dari kekurangan persediaan yang apabila itu terjadi dapat menyebabkan kerugian dan pelanggan kecewa. Penulis menggunakan metode transportasi untuk mencari solusi yang optimal.

\begin{tabular}{|c|c|c|c|c|c|c|}
\hline \multicolumn{5}{|l|}{$\begin{array}{l}\text { - Shortages } \\
C \text { Not allowed } \\
\text { C Backordered }\end{array}$} & \multicolumn{2}{|c|}{$\begin{array}{l}\text { Instruction } \\
\text { This cell can not be changed. }\end{array}$} \\
\hline Period & Demand & $\begin{array}{r}\text { Regular } t m \\
\text { Capacity }\end{array}$ & \begin{tabular}{l|} 
Overtime \\
Capacity
\end{tabular} & $\begin{array}{r}\text { Subcontract } \\
\text { Capacity }\end{array}$ & Unit costs & Value \\
\hline November & 1928,355 & 1333,25 & 1066,6 & 0 & Regular time & 31107730 \\
\hline December & 1630,162 & 1386,58 & 1066,6 & 0 & Overtime & 30568050 \\
\hline January & 1779,259 & 1333,25 & 1066,6 & 0 & Subcontracting & 0 \\
\hline February & 1704,71 & 1279,92 & 1066,6 & 0 & Holding cost & 1106319,0 \\
\hline March & 1741,984 & 1386,58 & 1066,6 & 0 & Backorder cost & 0 \\
\hline April & 1723,347 & 1333,25 & 1066,6 & 0 & & \\
\hline May & 1732,666 & 1279,92 & 1066,6 & 0 & & \\
\hline June & 1728,007 & 1386,58 & 1066,6 & 0 & Initial Inventory & 0 \\
\hline July & 1730,336 & 1279,92 & 1066,6 & 0 & & \\
\hline August & 1729,172 & 1386,58 & 1066,6 & 0 & & \\
\hline September & 1729,754 & 1333,25 & 1066,6 & 0 & & \\
\hline October & 1729,463 & 1333,25 & 1066,6 & 0 & & \\
\hline
\end{tabular}

Gambar 5: Biaya pada Mixed Strategy

Sumber: Hasil Pengolahan Data, 2015

\section{KESIMPULAN DAN SARAN}

Berdasarkan uraian dan pembahasan pada bab sebelumnya, maka penulis menarik kesimpulan sebagai berikut:

Dari hasil peramalan permintaan perusahaan pada periode perencanaan November 2015-Oktober 2016 yang telah diolah dengan menggunakan Linear Regression, Moving Average, Exponential Smoothing dan Weighted Moving Average dapat dilihat data tersebut menunjukkan data random yang permintaannya naik dan turun dalam waktu yang tidak menentu. Perhitungan peramalan yang paling tepat untuk diterapkan oleh perusahaan adalah metode Weighted Moving Average, karena memiliki nilai MAD dan MSE terendah yang dapat diartikan bahawa metode ini memiliki tingkat kesalahan yang rendah

Terdapat tiga alternatif strategi yang dapat diterapkan oleh perusahaan untuk menerapkan biaya produksi yang paling optimal, yaitu Chase Strategy, Level Strategy dan Mixed Strategy. Berdasarkan pengolahan data dengan menggunakan ketiga strategi tersebut dapat disimpulkan bahwa Mixed Strategy merupakan alternatif yang paling baik bagi perusahaan baik dari segi biaya yang paling rendah dan ketepatan waktu dalam memenuhi permintaan pelanggan dengan biaya sebesar Rp 642.846.000.000,00.

Saran yang dapat diberikan sebagai bahan pertimbangan bagi perusahaan adalah sebagai berikut:

Penulis menyarankan kepada perusahaan untuk melakukan peramalan secara terus menerus dikarenakan 
permintaan yang tidak menentu. Dengan peramalan permintaan yang baik, betujuan untuk mempermudah perusahaan untuk mengatur strategi produksi kedepannya.

Untuk periode perencanaan yaitu November 20115-Oktober 2016, solusi terbaik untuk diterapkan pada perusahaan adalah Mixed Strategy, karena strategi dengan pendekatan ini memiliki total biaya produksi paling optimal dibandingkan kedua strategi lainnya yaitu, Chase Strategy dan Level Strategy.

Apabila perusahaan ingin mengimplementasikan pendekatan subkontrak karena permintaan yang belum dapat terpenuhi, maka penulis menyarankan perusahaan memberikan standarisasi kualitas tertentu untuk rekan bisnis agar tidak mengurangi mutu dan kualitas produk, dikarenakan sisi negatif dari penerapan pendekatan subkontrak adalah kualitas produk yang dihasilkan tidak bisa diawasi dengan baik.

Penelitian ini terbatas hanya pada satu produk yang memiliki banyak permintaan berlebih, namun perusahaan belum bisa memenuhi sehingga terjadi keterlambatan. Untuk penelitian selanjutnya, penulis menyarankan untuk melakukan perencanaan agregat untuk semua produk di perusahaan jika diperlukan.

\section{DAFTAR PUSTAKA}

Dyck, B., \& Neubert, M. (2009). Principles of Management. SouthWestern: Cengage Learning.

Detiana, T. (2011). Manajemen Operasional Strategi dan Analisa Services dan Manufaktur. Jakarta: Mitra Wacana Media.

Herjanto, E. (2007). Manajemen Operasi (edisi ketiga). Jakarta: Grasindo.

Heizer, J. \& Render, B. (2009). Manajemen Operasi (edisi 9). Jakarta: Salemba Empat.
(2010).

Manajemen Operasi (buku 1 edisi 9). Jakarta: Salemba Empat.

Manajemen Operasi (edisi 11). Jakarta: Salemba Empat.

Prasetya, H., \& Lukiastuti, F., (2011). Manajemen Operasi. Yogyakarta: Media Presindo.

Robbins, S.P., \& Coulter, M. (2007). Management (9th edition). New Jersey: Prentice Hall, Pearson.

Management $\left(10^{\text {th }}\right.$ edition). New Jersey: Prentice Hall Inc.

Management ( $11^{\text {th }}$ edition). New Jersey: Prentice Hall, Pearson.

Rusdiana, H.A. (2014). Manajemen Operasi. Bandung: Pustaka Setia.

Stevenson, W. J., \& Chuong, S.S., (2014). Operations Management $\left(9^{\text {th }}\right.$ edition $)$ Jakarta: Salemba Empat.

Sriati. (2012, 9 Mei). Globalisasi Dan Perkembangan Bisnis. Diakses 8 Oktober 2015 http://blog.stiemce.ac.id/sriati/2012/05/09/globalis asi-dan-perkembangan-bisnis

Maskur, F. (2014, 11 Mei). INDUSTRI PIPA: Jenis Polyethylene Dongkrak Penjualan. diakses 8 Oktober 2015 http://industri.bisnis.com/read/ 20140511/257/226849/industripipa-jenis-polyethylene-dongkrakpenjualan

Hanczar, P \& Jakubiak, M. (2011). Aggregate planning in manufacturing company - linear programming approach. Total Logistic Management, 4, 69-76. (Online). Diakses 11 November 2015 dari http://journals.bg.agh.edu.pl/ TOTAL/2011/TLM_2011_05.pdf

Octavianti, I. A., Setyanto N. W., \& Tantrika, C.F.M. (2013). Perencanaan agregat produk tembakau rajang P01 dan P02 di PT 
X. 1(2), 264-274. (Online). Diakses 11 November 2015 dari https://www.academia.edu/8934497 I

PERENCANAAN_PRODUKSI_A GREGAT_PRODUK TEMBAKA U_RAJANG_P01_DAN_P02_DI PT_X_AGGREGATE_PRODUCT ION_PLANNING_FOR_TOBACC O_PRODUCTS_P01_AND_P02_I N PT X

Safi, S. K., \& Dawoud, I.A. (2013). Comparative study on forecasting accuracy among moving average models with simulation and PALTEL stock market data in Palestine. American Journal of
Theoretical and Applied Statistics, 2(6), 202-209. (Online). Diakses 11 November 2015 dari http://article.sciencepublishinggrou p.com/pdf/10.11648.j.ajtas.201302 06.17.pdf

Simamora, B. H., \& Natalia D. (2014). Aggregate planing for minimizing costs: A case study of PT XYZ in Indonesia. International Business Management, 8(6), 353-356. (Online). Diakses 11 November 2015 dari http://docsdrive.com/pdfs/medwellj ournals/ibm/2014/353-356.pdf 